\title{
Exposure of Paris taxi drivers to automobile air pollutants within their vehicles
}

\author{
Emmanuelle Zagury, Yvon Le Moullec, Isabelle Momas
}

\begin{abstract}
Objectives-To study the exposure of Parisian taxi drivers to automobile air pollutants during their professional activity.

Methods-A cross sectional study was carried out from 27 January to 27 March 1997, with measurements performed in the vehicles of 29 randomly selected drivers. Carbon monoxide (CO) content was measured over an 8 hour period by a CO portable monitor. The fine suspended particles were measured according to the black smoke index (BS), with a flow controlled portable pump provided with a cellulose filter. The nitrogen oxides, NO and $\mathrm{NO}_{2}$ were measured with a passive sampler.

Results-These drivers are exposed during their professional activity to relatively high concentrations of pollutants (mean, median (SD) 3.8, 2 (1.7) ppm for CO, 168, $164(53) \mu \mathrm{g} / \mathrm{m}^{3}$ for BS, 625, $598(224) \mu \mathrm{g} / \mathrm{m}^{3}$ for $\mathrm{NO}$, and $139,131(43) \mu \mathrm{g} / \mathrm{m}^{3}$ for $\mathrm{NO}_{2}$.) For CO the concentrations were clearly lower than the threshold values recommended by the World Health Organisation. The situation is less satisfactory for the other pollutants, especially for the BS index. All concentrations of pollutants recorded were noticeably higher than concentrations in air recorded by the ambient Parisian air monitoring network and were close to, or slightly exceeded, the concentrations measured at the fixed stations close to automobile traffic. Pollutant concentrations were also influenced greatly by weather conditions.

Conclusion-This first French study conducted in taxi drivers shows that they are highly exposed to automobile pollutants. The results would justify a medical follow up of this occupational group.

(Occup Environ Med 2000;57:406-410)
\end{abstract}

Keywords: taxi drivers; exposure assessment

For the past 30 years in the Parisian agglomeration, as in most large cities, pollution resulting from fixed combustion installations (power stations, collective and individual heating) and from industrial activities has clearly decreased, resulting in a decrease in concentrations of sulphur dioxide $\left(\mathrm{SO}_{2}\right)$, and to a lesser extent, in fine suspended particles. Over the same period, the progress achieved in unit emission of new cars has been partially offset by the continued increase in the number of cars. Although decreases in concentrations of lead and carbon monoxide (CO) have been found, this is not so for nitrogen oxides and ozone $\left(\mathrm{O}_{3}\right)$, for which indicators have shown no clear tendency over the past 10 years. ${ }^{1}$

Air monitoring networks provide much information on concentrations of pollutants in conglomerations, but the personal exposure of citizens to automobile air pollution is less well known. Various studies, ${ }^{2-12}$ some of which were carried out in Paris ${ }^{11}{ }^{12}$ have shown that people are most exposed inside their cars, and that pollution comes primarily from neighbouring cars.

Hence our interest in finding the exposure to automobile air pollutants in a group of taxi drivers. The aim was to measure four pollutants characteristic of automobile pollution, inside the vehicles of randomly chosen taxi drivers:

- Carbon monoxide

- Fine suspended particles assessed by the black smoke index (BS)

- Nitrogen oxides $\mathrm{NO}$ and $\mathrm{NO}_{2}$.

\section{Material and methods}

This descriptive cross sectional study was carried out from 27 January to 27 March 1997. A sample of 203 subjects was randomly selected from the National Federation register of 6164 self employed Parisian taxi drivers. A large sample was chosen in anticipation of a low response rate resulting from the constraints imposed by participation in the study. Drivers had the inconvenience of going out of their way to pick up and return the hardware, losing time which is valuable to a professional whose activity depends on time spent on duty.

The reply rate to the first letter requesting their participation was $23 \%$, reaching $52.7 \%$ after a rerun. Fifty five drivers responded favourably, and of those 29 were retained as they corresponded to the study criteria - that is, they worked during the daytime, were nonsmokers, and did not permit smoking in their taxis. Only drivers working during the day were chosen for the study, to constitute as homogeneous and representative a sample as possible. Results reported in an investigation into the activity of Parisian self employed taxi drivers ${ }^{13}$ showed that only $7.4 \%$ of them worked at night. The exclusion of smokers was necessary to avoid interference with measurements.

The study was conducted with monitors of established reliability. All methods of analysis used had also been previously validated.

Carbon monoxide was measured over an 8 hour period by a PAC II CO (Draeger industry) portable monitor, with an electrochemical detection cell with a measuring 
capacity of $0-500 \mathrm{ppm}$. Readings were made every 3 seconds, and the data collection system was linked to a sensor programmed to calculate the average of these readings at 1 minute intervals during the trip. This method of measurement has been validated inside cars by our team and has been compared favourably with sampling by Tedlar bags and analysis by infrared spectrometry.

The fine suspended particles were measured according to the BS index (French standard method NF-X 43-005) which is largely used in Europe (OECD method $\left.{ }^{14}\right)$. Measurement consisted of active sampling during an 8 hour period, with a flow controlled portable SKC pump provided with a cellulose filter. Collection filters were analysed by reflectometry in the laboratory.

Nitrogen oxides were measured with an OGAWA passive sampler, ${ }^{15}$ which efficiently collects these on two precoated filter pads: one adsorbing $\mathrm{NO}_{2}$, the other adsorbing $\mathrm{NO}$ and $\mathrm{NO}_{2}$. The two filter pads were extracted separately into water, and analysis was by standard colorimetry. During the study, comparison was performed between $17 \mathrm{NO}$ and 17 $\mathrm{NO}_{2}$ concentrations measured at the same site, by both OGAWA passive samplers, and by a chemiluminescence analyser. The correlations were highly significant (Pearson correlation coefficient $r=0.96$ for $\mathrm{NO}, r=0.91$ for $\left.\mathrm{NO}_{2}\right)$. On average, the two series of measurements did not differ significantly ( $p>0.05)$.

The days chosen for measurement were determined by random selection from each drivers' schedule, to get the most representative readings. The portable $\mathrm{CO}$ monitor, and the SKC particle pump, were placed on the front passenger's seat for 8 hours. The OGAWA passive sampler was placed on the same seat, but left for 3 days to cover a 24-30 hour period. Drivers were told to keep the badge in its case at night, so that exposure to nitrogen oxides was only during their professional activity.

For measurements of CO and BS, taxi drivers filled out report sheets to give details about their car, as well as other variables related to the exposure measurements - such as work hours, duration of the daily itinary, type of streets patrolled, duration of service interruptions, and ventilation in the vehicle. For nitrogen oxides, a sheet indicating exposure hours was filled out by each driver.

Meteorological data for the study were provided by the Paris Montsouris meteorological station (Meteo-France weather station).

The ambient air pollution was measured in urban background stations of the existing monitoring network (AIRPARIF), especially in the station located in the centre of Paris, and at two other sites close and very close to automobile traffic. In these sites, the concentration of BS was measured by reflectometry (French standard method NF-X 43-005), $\mathrm{NO}$ and $\mathrm{NO}_{2}$ by chemiluminescence, and $\mathrm{CO}$ by infrared spectrometry.

Data acquisition and statistical analysis were carried out with BMDP software (California University). For each driver, mean exposure to $\mathrm{CO}$ was calculated starting from the data recorded every minute by the monitor; the BS, $\mathrm{NO}$, and $\mathrm{NO}_{2}$ concentrations were added over the different exposure times. For each pollutant, the mean exposure of the 29 drivers and the corresponding SD were calculated from individual means. These results were compared with World Health Organisation (WHO) guide values and average air pollutant concentrations measured at the same hours on the same days by the AIRPARIF air monitoring network analysers. The comparison of means was based on variance analysis (Brown Welch test in the event of non-equality of variances). Correlations were examined with the Pearson test.

Analysis of variance (ANOVA) was used to study the role of different factors on $\mathrm{CO}$ concentrations inside the vehicles. The factors were meteorological conditions (wind strength, precipitations, external temperature, change of temperature, relative humidity, and atmospheric pressure) and driving conditions (duration of service interruptions, duration and type of the daily itinerary, and presence of air conditioning). The role of these factors was also studied for BS. Finally, a multiple linear stepwise regression was performed to confirm results from bivariate analyses. Results of the tests were considered as significant if the $p$ value was $<0.05$.

\section{Results}

EXPOSURE OF TAXI DRIVERS TO MEAN CONCENTRATIONS OF DIFFERENT AIR POLLUTANTS

The CO measurements were carried out on 28 out of the 29 drivers, 26 of them throughout their working day of about 8 hours, and the remaining two for 4 and 6 hours. All drivers apart from one had a car with a diesel engine, with 53\% having air conditioning. However, most of those with air conditioning did not use it due to the weather conditions. The mean (SD) distance travelled during the observation period was $131(46) \mathrm{km} ; 73 \%$ of the drivers stayed mainly inside Paris for $>75 \%$ of the time, whereas the remaining $25 \%$ were active mostly in the three departments close to Paris. The mean duration of service interruptions during measurements was close to 2 hours, these being primarily stationary waiting time. Mean exposure to $\mathrm{CO}$ was 3.8 (1.7) ppm (fig $1)$. The 1 minute $\mathrm{CO}$ histogram shows that most values ranged from 0 to $4 \mathrm{ppm}$, with a maximum at $2 \mathrm{ppm}$, which represents the median of distribution. Also, the 1 minute graphical representation (fig 2) indicates that some of the drivers were exposed to high values over short periods, reaching as high as 35-40 ppm, and even $52 \mathrm{ppm}$. All drivers had many peaks between 15 and $25 \mathrm{ppm}$.

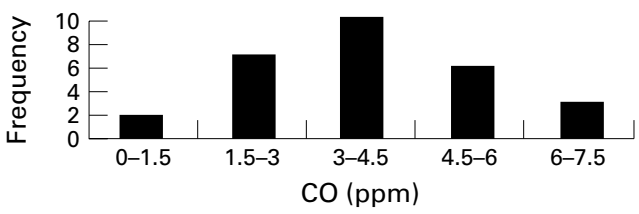

Figure 1 Mean concentrations of exposure of taxi drivers to different air pollutants: CO histogram. 


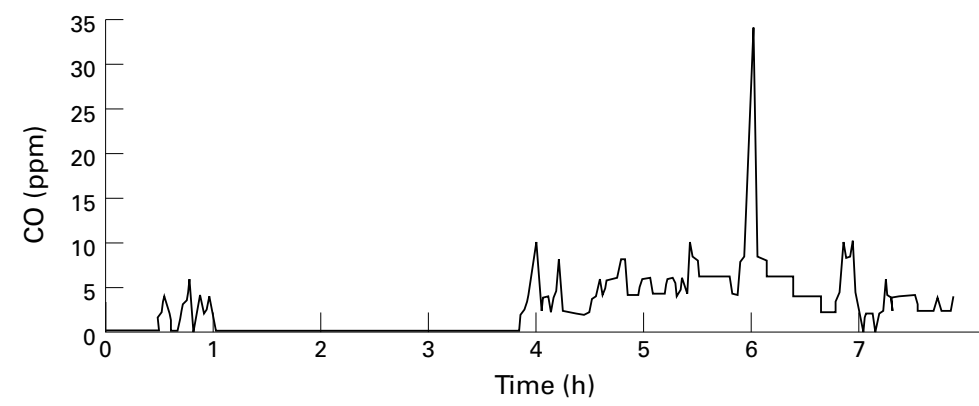

Figure 2 Mean concentrations of exposure of taxi drivers to different air pollutants: representation of 1 minute $C O$ for one taxi driver.

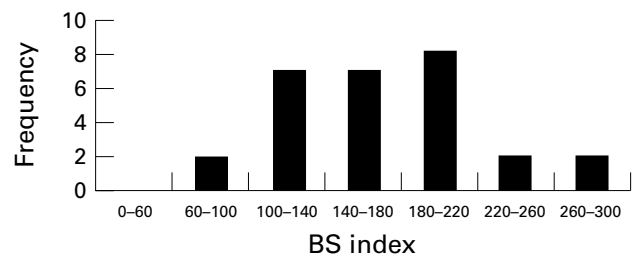

Figure 3 Mean concentrations of exposure of taxi drivers to different air pollutants: BS index histogram.

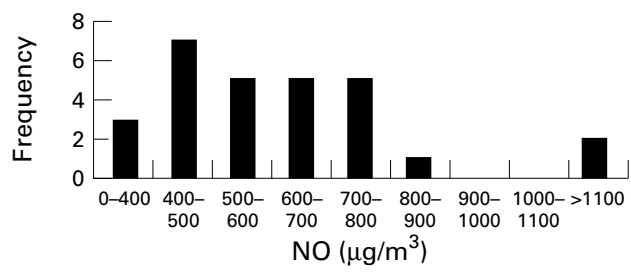

Figure 4 Mean concentrations of exposure of taxi drivers to different air pollutants: NO histogram.

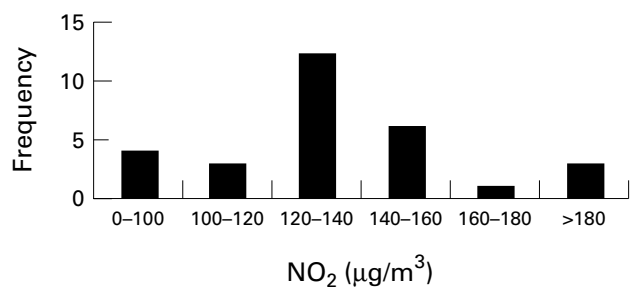

Figure 5 Mean concentrations of exposure of taxi drivers to different air pollutants: $\mathrm{NO}_{2}$ histogram.

The BS index was obtained for 28 out of the 29 drivers (one pump did not work), with sampling being carried out over a period of about 8 hours, apart from one driver, whose duration was 6 hours. The mean BS index was 168 (53) $\mu \mathrm{g} / \mathrm{m}^{3}$. The distribution histogram (fig 3) shows a median at $164 \mu \mathrm{g} / \mathrm{m}^{3}$. There was a good correlation between the $\mathrm{BS}$ index and $\mathrm{CO}$ concentrations $(r=0.55(\mathrm{p}<0.02))$.

Measurements of nitrogen oxides were carried out for the 29 drivers (28 items of data were collected for $\mathrm{NO}$ ). Mean $\mathrm{NO}$ and $\mathrm{NO}_{2}$ concentrations were $625(224) \mu \mathrm{g} / \mathrm{m}^{3}$ and 139 (43) $\mu \mathrm{g} / \mathrm{m}^{3}$, respectively. Median values of $\mathrm{NO}$ and $\mathrm{NO}_{2}$ (figs 4 and 5) were $598 \mu \mathrm{g} / \mathrm{m}^{3}$ for $\mathrm{NO}$ and $131 \mu \mathrm{g} / \mathrm{m}^{3}$ for $\mathrm{NO}_{2}$.

Comparison was made between mean concentrations of the different pollutants obtained in the taxi drivers' vehicles, and those recorded at the Parisian air monitoring network AIRPARIF fixed stations.

The mean concentrations of air pollutants in the taxi drivers' cars were, whatever the pollutant, significantly higher than those recorded on the same days and times at the AIRPARIF urban background stations. Concentrations of nitrogen oxides measured in cars were higher than those recorded at sites with a high volume of automobile traffic, whereas concentrations of $\mathrm{CO}$ and fine suspended particles were equivalent (table 1).

There were good correlations between CO, BS, and NO concentrations of air pollution obtained in the taxi drivers' cars, and concentrations recorded by the various AIRPARIF fixed stations (table 2). No correlation was found for $\mathrm{NO}_{2}$ concentrations with the values of the air monitoring network, whatever the site.

INFLUENCE OF EXTERNAL FACTORS

The multiple linear stepwise regression model emphasised for $\mathrm{CO}$ the significant role of two variables inversely associated with $\mathrm{CO}$ concentrations. The first was wind strength $(0.001<p<0.01)$, the second the duration of service interruptions $(p<0.01)$. Drivers who drove in a strong wind recorded lower CO concentrations than those who did not (2.8 and $4.2 \mathrm{ppm}$, respectively). A similar difference was recorded for drivers who had stopped for $>2$ hours (3.3 and $4.3 \mathrm{ppm}$, respectively). These two variables explained $55 \%$ of the variability of $\mathrm{CO}$ concentrations inside the vehicles.

Multivariate analysis showed that concentrations of black smoke inside cars were explained by only one variable, the wind strength $(\mathrm{p}<0.001)$. As with CO, drivers who drove in strong winds recorded a lower BS index than the others $\left(128\right.$ and $\left.195 \mu \mathrm{g} / \mathrm{m}^{3}\right)$. This factor explained $39 \%$ of the variability of the BS index inside the vehicles. None of the other factors studied had significant influences on the concentrations of these two pollutants.

\section{Discussion}

The investigation was carried out on a sample of 29 taxi drivers, working during the day and chosen at random. They constitute as homogeneous and representative a sample as possible, according to results reported in an investigation into the activity of Parisian self employed taxi drivers ${ }^{13}$ which showed that $93 \%$ of them work during daytime, $96 \%$ have a diesel

Table 1 Values of different pollutants (mean (SD)) obtained in taxis and those recorded at the Paris air monitoring network fixed stations

\begin{tabular}{|c|c|c|c|c|c|c|c|c|c|c|c|}
\hline & \multicolumn{2}{|c|}{ Taxis } & \multicolumn{2}{|c|}{$\begin{array}{l}\text { Urban } \\
\text { background }\end{array}$} & \multirow{2}{*}{$\frac{p \text { Value }}{<0.0001}$} & \multicolumn{2}{|c|}{$\begin{array}{l}\text { Close to motor } \\
\text { vehicle traffic }\end{array}$} & \multirow{2}{*}{$\frac{p \text { Value }}{<0.0001}$} & \multicolumn{2}{|c|}{$\begin{array}{l}\text { High automobile } \\
\text { traffic volume }\end{array}$} & \multirow{2}{*}{$\frac{p \text { Value }}{>0.05}$} \\
\hline $\mathrm{CO}(\mathrm{ppm})$ & & $(1.70)$ & & $(0.46)$ & & & $(0.56)$ & & & $(1.0)$ & \\
\hline BS $\left(\mu \mathrm{g} / \mathrm{m}^{3}\right)$ & 168 & (53) & & (29) & $<0.0001$ & 89 & (24) & $<0.0001$ & 141 & (47) & $>0.05$ \\
\hline $\mathrm{NO}\left(\mu \mathrm{g} / \mathrm{m}^{3}\right)$ & 625 & (223) & 55 & (30) & $<0.0001$ & 139 & (30) & $<0.0001$ & 386 & (74) & $<0.0001$ \\
\hline $\mathrm{NO}_{2}\left(\mu \mathrm{g} / \mathrm{m}^{3}\right)$ & 139 & (43) & 72 & (22) & $<0.0001$ & 84 & (22) & $<0.0001$ & 117 & (19) & $=0.01$ \\
\hline
\end{tabular}


Table 2 Correlation * between $\mathrm{CO}, \mathrm{BS}, \mathrm{NO}$, and $\mathrm{NO}_{2}$ concentrations obtained in the taxis, and concentrations recorded at the Paris air monitoring network fixed stations

\begin{tabular}{lllllll}
\hline & $\begin{array}{l}\text { Correlation } \\
\text { between taxis and } \\
\text { urban background } \\
\text { sites }(r)\end{array}$ & $p$ Value & $\begin{array}{l}\text { Correlation } \\
\text { between taxis } \\
\text { and close to } \\
\text { traffic sites }(r)\end{array}$ & $p$ Value & $\begin{array}{l}\text { Correlation } \\
\text { between taxis } \\
\text { and heavy } \\
\text { traffic sites }(r)\end{array}$ & $p$ Value \\
\hline $\mathrm{CO}$ & 0.69 & $=0.001$ & 0.57 & $<0.001$ & 0.71 & $=0.001$ \\
$\mathrm{BS}$ & 0.55 & $=0.002$ & 0.34 & $=0.055$ & 0.40 & $=0.03$ \\
$\mathrm{NO}$ & 0.62 & $=0.001$ & 0.31 & $>0.05$ & 0.42 & $=0.02$ \\
$\mathrm{NO}_{2}$ & 0.25 & $>0.05$ & 0.16 & $>0.05$ & 0.22 & $>0.05$
\end{tabular}

$r=$ Pearson correlation coefficient.

engined car, and half of them have air conditioning.

Mean (SD) CO concentration was relatively low 3.8 (1.7) ppm, lower than the 8 hour WHO guide value of $10 \mathrm{ppm} .{ }^{16}$ It was also lower than the concentrations reported in two studies ${ }^{11} 12$ carried out in Paris that measured CO inside the car for about 90 minutes. The first study ${ }^{11}$ reported a mean $\mathrm{CO}$ content of $12 \mathrm{ppm}$ obtained during a period of about 60 minutes from 90 home to work journeys in Paris and its suburbs. The second study ${ }^{12}$ reported a mean $\mathrm{CO}$ content of $9 \mathrm{ppm}$. Similar results have been found in the United States, where Ott et $a l^{7}$ reported a mean $\mathrm{CO}$ content of $9.8 \mathrm{ppm}$ from the same car during 88 short journeys of 11.8 miles in an urban area. The relatively low mean obtained in our study is primarily explained by the fact that recordings were carried out over 8 hours, including service interruptions. Recordings for 2, and even 4 hours, showed a very clear decrease in values, which can fall to nil when stationary waiting periods occur away from the flow of traffic. The mean obtained thus represents the real exposure of these drivers to CO during their working day. This low concentration is in keeping with the change in the annual mean $\mathrm{CO}$ content recorded at the Paris air monitoring network fixed station near automobile traffic (3.4 ppm in 1993, $3.2 \mathrm{ppm}$ in 1995, and $2.5 \mathrm{ppm}$ in 1997). This change is due to the European regulations on petrol engine vehicles (catalytic converters) and the increase in diesel engine vehicles in the French automobile fleet. Nevertheless, the real exposure of taxi drivers could be underestimated, some peaks might have been missed when drivers moved outside their cars while the engine was on, for instance when picking up a passenger.

Very high values were found for drivers over short periods, such as $40 \mathrm{ppm}$ for a few minutes and there were many peaks of 10-15 ppm. These values are still lower than the maximum value for exposure of $\mathrm{CO}$ recommended by the WHO, which is 90 ppm over a period of 15 minutes. ${ }^{16}$ The high values were mainly found during rush hours (0700-0900, 1700-1900), which suggests that they correspond to halts caused by traffic jams.

The mean (SD) value of the BS index over 8 hours $\left(168(53) \mu \mathrm{g} / \mathrm{m}^{3}\right)$, is higher than the maximum guide value of $125 \mu \mathrm{g} / \mathrm{m}^{3}$ over 24 hours recommended by the WHO. ${ }^{17}$ These two values, however, which were measured over different exposure durations, are not directly comparable. If an exposure of 12 hours in the vehicle and 12 hours at home with a concentra- tion of about $20 \mu \mathrm{g} / \mathrm{m}^{3}$ is considered (mean urban concentration), the mean value over 24 hours is about $95 \mu \mathrm{g} / \mathrm{m}^{3}$; this value has to be compared with the WHO value of $125 \mu \mathrm{g} / \mathrm{m}^{3}$.

The BS index is not the best indicator for assessing exposure to particulate matter, but was the only method feasible in this context for several reasons - in particular, sampling duration was limited to 8 or 10 hours, and it was necessary to use a small and silent personal pump. This index is not a measurement of $\mathrm{PM}_{10}$ or $\mathrm{PM}_{2.5}$ but is correlated with these measurements in European urban areas. ${ }^{18}$ According to Muir and Laxen, ${ }^{18}$ daily average $\mathrm{BS}$ is a reasonable predictor of daily mean $\mathrm{PM}_{10}$ and of daily peak 1 hour $\mathrm{PM}_{10}$. However, different relations apply to winter and summer, showing that these methods are measuring different components of fine airborne particles. This relation also depends on proximity to traffic. The black smoke method has been established when the main source of airborne particles was coal combustion; the relation between $\mathrm{PM}_{10}$ and $\mathrm{BS}$ is still the same for measurements in urban background sites. Nevertheless, this association is different near traffic, which is the main source for black carbon and which emits only small amounts of non-black particles. This can explain why the BS index is very high inside taxi cars whereas $\mathrm{PM}_{10}$ concentrations are likely to be lower.

Mean (SD) concentrations of $\mathrm{NO}$ and $\mathrm{NO}_{2}$ in taxis (625 (224) and $139(43) \mu \mathrm{g} / \mathrm{m}^{3}$, respectively) were also increased. Concentrations of $\mathrm{NO}_{2}$ are not, however, directly comparable with the daily WHO guide value of $150 \mu \mathrm{g} / \mathrm{m}^{317}$ as $\mathrm{NO}_{2}$ concentrations represent three periods of 10 hours, whereas the daily WHO guide value is over 24 hours. In fact, the daily exposure of a taxi driver, including the time spent outside work, is probably lower than 150 $\mu \mathrm{g} / \mathrm{m}^{3}$, as ambient urban concentrations are about $50 \mu \mathrm{g} / \mathrm{m}^{3}$.

Comparison between mean concentrations in taxis and those recorded at the background AIRPARIF site shows that drivers are exposed during their working day to concentrations more than 10 times higher for NO, four times higher for BS, more than three times higher for $\mathrm{CO}$, and twice as high for $\mathrm{NO}_{2}$.

These results agree with those obtained in other studies, ${ }^{4-81112}$ where authors found major differences between the concentrations measured within the vehicle and those recorded at the air monitoring network fixed stations. In the Parisian conglomeration, for instance, Dor et $a l^{11}$ reported CO concentrations 6-8 times greater inside cars than those recorded at the background site. Similar differences were reported by Fernandez Bremauntz and Ashmore ${ }^{8}$ in Mexico City.

Drivers are exposed to concentrations of $\mathrm{CO}, \mathrm{BS}, \mathrm{NO}$, and $\mathrm{NO}_{2}$ that are about twice as high as those at sites close to motor vehicle traffic, and equal to those recorded at the site of high automobile traffic volume at the edge of the ring road of Paris, and at a very busy crossroads.

Inside cars, as expected, concentrations of $\mathrm{NO}$ were notably higher than those of $\mathrm{NO}_{2}$, as 
$\mathrm{NO}$ is a primary pollutant emitted directly in exhaust fumes. Two drivers had very high concentrations of NO $\left(1245\right.$ and $\left.1310 \mu \mathrm{g} / \mathrm{m}^{3}\right)$ and of $\mathrm{NO}_{2}\left(194\right.$ and $\left.320 \mu \mathrm{g} / \mathrm{m}^{3}\right)$. These results are difficult to explain, as they did not seem to have any special distinguishing characteristics (their $\mathrm{CO}$ and BS concentrations were no higher than those for other drivers). The only possible explanation is that the reported duration of exposure of these two drivers was shorter than the actual sampling duration, leading to an overestimation of $\mathrm{NO}$ and $\mathrm{NO}_{2}$ concentrations. Indeed, the absence of control over durations of sampling of badges inside the cars does bring the method used into question. However, after removing these two high values from the analysis, mean $\mathrm{NO}$ and $\mathrm{NO}_{2}$ concentrations were not significantly changed $\left(575 \mu \mathrm{g} / \mathrm{m}^{3}\right.$ for $\mathrm{NO}$ and $131 \mu \mathrm{g} / \mathrm{m}^{3}$ for $\mathrm{NO}_{2}$ ).

The good correlations between concentrations of $\mathrm{CO}, \mathrm{BS}$, and $\mathrm{NO}$ inside cars and at the background station, suggest that concentrations of air pollutants fluctuate according to certain external factors that are similar to both situations.

The first of these external factors is the weather, with results clearly showing a significant difference between means for $\mathrm{CO}$ and BS when drivers operated during strong winds. These results are comparable with those obtained in other studies, ${ }^{9}{ }^{10} 12$ in which authors have shown that the higher the wind speed, the lower the concentrations of pollutants measured inside cabs. Dendène ${ }^{12}$ for example, reported that an intensification of the wind speed from $1 \mathrm{~m} / \mathrm{s}$ to $4 \mathrm{~m} / \mathrm{s}$ resulted in a $30 \%-40$ $\%$ reduction in $\mathrm{CO}$ exposure.

The second factor influencing concentrations of pollutants in taxis is traffic conditions. The profiles of various $\mathrm{CO}$ recordings showed considerable concentrations for most drivers at rush hours (0700-0900, and 1700-1900), when free movement of traffic is most difficult. Generally speaking, studies have shown that traffic intensification leads to an increase in concentrations inside the vehicles. ${ }^{9-12}$ This phenomenon is mainly explained by an increase in the number of polluting sources and a reduction in the distances between the vehicles. Khouski et $a l^{10}$ reported that an increase from 1000 to 5000 vehicles led to an increase in $71 \%$ for mean $\mathrm{CO}$ concentration.

Studies carried out in other major conglomerations have shown significant differences in exposure of drivers between the city centre, the suburbs, and the surrounding rural area. Chan et $a l^{\beta}$ reported a CO gradient of $13 / 11 / 3 \mathrm{ppm}$ between Raleigh (North Carolina) city centre, its suburbs, and its rural area, whereas in the Paris conglomeration, ${ }^{11}$ in 1992 , the gradient was $12 / 7 / 1 \mathrm{ppm}$. This reduction in concentrations from the urban environment to the rural areas reflects the difference in traffic density and speed. In our study, one surprising result was that the drivers who spent $75 \%$ of their time inside Paris city centre, which is known to have very high concentrations of pollutants, did not have mean concentrations of $\mathrm{CO}$ and BS that were significantly different from drivers working mainly in the suburbs. One possible explanation for this is a lack of statistical power due to the small size of the sample.

Durations of service interruptions are linked with CO concentrations, as drivers stop mainly outside the traffic flow. There was no significant difference between taxis with or without air conditioning, as most drivers did not use the air conditioning during the measurement period, in winter.

In summary, to the best of our knowledge, this study is the first in France to measure exposure of taxi drivers to automobile air pollution. This exposure is high and could justify a medical follow up of this occupational group.

We are grateful to taxi drivers who accepted to participate in this study. We also thank Mr Arianer, Banel, Estival, and Langeais from the National Federation of self employed taxi drivers.

1 Association Interdépartementale pour la gestion du Réseau de mesure de la Pollution Atmospherique et d'alerte en Région d'Ile.de.France. Surveillance de la qualité de l'air en Ile de France: les résultats, 1996. Paris: AIRPARIF, 1996.

2 Flachsbart PG, Mack GA, Howes JE, et al. Carbon monoxide exposures of Washington commuters. F Air Pollut Control Assoc 1987;37:135-42.

3 Chan CC, Ozkaynak H, Spengler JD, et al. Driver exposure to volatile organic compounds, $\mathrm{CO}$, ozone, and $\mathrm{NO}_{2}$ under different driving conditions. Environment Science and Technology 1991;25:964-72.

4 Liu CS, Shikiya D, Kahn MI, et al. In-vehicle air toxics characterization study in the Los Angeles region of California. Proceeding of the 8th World Clean Air Congress, 11-15 september 1989. The Hague, The Netherlands: 1989;1;247-52.

5 Van Wijnen JH, Verhoeff AP, Jans HWA, et al. The exposure of cyclists, car drivers and pedestrians to traffic-related air pollutants. Int Arch Occup Environ Health 1995;67:187-93.

6 Jo WK, Choi SJ. Vehicle occupants' exposure to aromatic volatile organic compounds while commuting on an urbansuburban route in Korea. F Air Waste Manage Assoc 1996;46:749-54

7 Ott W, Switzer P, Willits N. Carbon monoxide exposures inside an automobile traveling on an urban arterial highway. $\mathcal{F}$ Air Waste Manag Assoc 1994;44:1010-18.

8 Fernandez Bremauntz AA, Ashmore MR. Exposure of commuters to carbon monoxide in Mexico City II. Comparison of in-vehicle and fixed-site concentrations. 7 Expos Anal Environ Epidemiol 1995;5:497-510.

9 Weisel CP, Lawryk NJ, Lioy PJ. Exposure to emissions from gasoline within automobile cabins. I Expo Anal Environ Epidemiol 1992;1:79-96.

10 Koushki PA, Al Dhowalia KH, Niaizi SA. Vehicle occupant exposure to carbon monoxide. F Air Waste Manag Assoc 992;42:1603-8.

11 Dor F, Le Moullec Y, Festy B. Exposure of city residents to carbon monoxide and monocyclic aromatic hydrocarbons during commuting trips in the Paris metropolitan area. $\mathcal{f}$ Air Waste Manag Assoc 1995;45:103-10.

12 Dendene MA. Exposition au monoxyde de carbone et aux hydrocarbures aromatiques monocycliques. Etude comparative des divers modes de déplacements urbains et recherche de biomarqueurs dans l'air expiré [thèse pour l'obtention du diplôme d'Etat de Docteur en Pharmacie]. Paris: Université René Descartes, 1995.

13 Zagury E, Momas I, Le Moullec Y, et al. Enquête auprès des chauffeurs de taxi artisans parisiens: perception de la pollution d'origine automobile. Pollution Atmosphérique pollution d'origin

14 Smoke. In: Methods of measuring air pollution. Paris: Organisation for Economic Co-operation and Development, 1964: 2. (Publ No 17913 .)

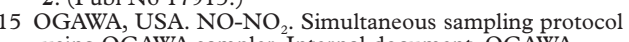
using OGAWA sampler. Internal document. OGAWA.

16 World Health Organisation. Guidelines for air quality. Geneva: WHO, 1999.

17 World Health Organisation. Air quality guidelines for Europe. Copenhagen: WHO, 1987. (WHO regional publications, European series $\mathrm{N}^{\circ} 23$.)

18 Muir D, Laxen DPH. Black smoke as a surrogate for $\mathrm{PM}_{10}$ in health studies. Atmospheric Environment 1995;29:95962 . 